\title{
ФОРМУВАННЯ ПРОФЕСІЙНОЇ КОМПЕТЕНТНОСТІ \\ СЛУХАЧІВ НАВЧАЛЬНОГО ЗАКЛАДУ ГАЛУЗІ \\ ПРОФЕСІЙНО-ТЕХНІЧНОЇ ОСВІТИ
}

Олло В. П., Сакно О. П.

\section{ВСТУП}

Загострення соціально-економічної кризи вагомо впливає на рівень криміногенної ситуації в Україні. Зростання функції пенітенціарних установ у сучасності спрямоване на повернення суспільству адаптованого, повноцінного та працездатного громадянина. Це - генеральне завдання для забезпечення національної політики та національної безпеки державності. Дослідникам та науковцям у галузі пенітенціарної педагогіки пропонується організувати навчальну діяльність засуджених у контексті загальних проблем держави. Це невід'ємний складник роботи професійно-технічної освіти (ПТО). Наявна пенітенціарна структура характеризується обов'язковим поліпшенням стану й тенденцією розвитку, тобто нестихаючим та актуальним фактором проблеми, що потребує особливої уваги, докладання значних зусиль та невідкладного вирішення ${ }^{1}, 2$.

Трансформація освітньої парадигми у місцях позбавлення волі потребує розширення та поглиблення наукових досліджень у галузі ПТО. Засуджені під час відбування покарань отримують можливість придбання робітничої професії та поліпшення отриманого протягом життєдіяльності практичного досвіду щодо можливості подальшого працевлаштування за підтримкою виробництва установи виконання покарань.

Вимоги законодавчих нормативів під час навчального процесу у професійно-технічних навчальних закладах системи органів й установ виконання покарань урегульовані Конституцією України; Кримінально-виконавчим кодексом України; законами України «Про освіту», «Про професійно-технічну освіту»; Положенням про професійно-технічний навчальний заклад, затвердженим Постановою Кабінету Міністрів України від 5 серпня 1998 р. № 1240 «Про професійно-технічну освіту»; спільним наказом Міністерства освіти і науки України та Державного департаменту України 3 питань виконання

\footnotetext{
1 Gąsior K. Diversifying childhood experiences of Adult Children of Alcoholics. Alcoholism and Drug Addiction. Elsevier. 2014. Vol. 27(4). P. 289-304. URL: https://www.sciencedirect.com/ science/article/pii/S0867436114700215
}

2 Stepanenko M. Magazine “Foreign education”. 2003. Vol. 2. 
покарань від 26.02.2004 № 153/32 «Про затвердження Положення навчальних центрів при установах виконання покарань»; Положенням про організацію навчально-виробничого процесу у професійно-технічних навчальних закладах, затвердженим наказом Міністерства освіти і науки України від 30 травня 2006 року № 419, зареєстрованим у Міністерстві юстиції України 15 червня 2006 року № 711/12585; Положенням про навчальний центр при кримінально-виконавчій установі закритого типу, затвердженим спільним наказом Міністерства освіти і науки України та Міністерства юстиції України від 19 грудня 2013 року № 1794/2691/5, зареєстрованим у Міністерстві юстиції України від 25 грудня 2013 року № 2192/24724, та іншими нормативно-правовими актами, що регулюють відносини у галузі освіти пенітенціарної структури, й наявними Статутами навчальних центрів при установах виконання покарань та забезпечення прав громадян України щодо придбання професійної освіти відповідно до нахилів, здібностей та інтересів з метою поліпшення умов адаптації осіб після відбування покарань $з$ місць позбавлення волі.

Процес професійного навчання існує на базі розвитку особистості слухача, враховуючи освітній рівень, життєвий досвід та робочий стаж. Процедура, що вимагає тривалого періоду формування професійної спрямованості, є невід'ємним чинником формування професійної спрямованості слухачів навчальних закладів при установах виконання покарань щодо утворення вибірково-позитивного ставлення індивіда під час професійної діяльності або часткової зайнятості у зазначеній галузі ${ }^{3}$. Найважливішим результатом щодо виконання цілей професійної підготовки майбутнього фахівця зазначається виховання готовності до професійної діяльності з підвищеною здатністю. У навчальному процесі слід відносити формування навчальної підготовки та здійснення професійних обов'язків сумісно фахівцями навчального закладу та установи виконання покарань. Вимоги до професійної діяльності, професійного досвіду, особових властивостей стану особи та психологічних процесів, що протікають, визначаються здатністю індивіда під час виконання функцій ПТО.

Невід’ємним складником готовності фахівця до професійної діяльності є тільки система професійних вмінь, знань та навичок ${ }^{4}$. Таким

\footnotetext{
3 Diukareva M.M. Project representation "Education Reforming" (Personality formation programs introduction into Educational system). Procedia - Social and Behavioral Sciences. 2016. Vol. 217. P. 626-630. DOI: 10.1016/j.sbspro.2016.02.076.

4 Stratiev B. Osnovni mezhdunarodni aktove po penitentsiarno pravo. Zatvorno delo, kn. 3 , 2011. P. 15-27.
} 
чином, у структуру готовності слухача професійно-технічних навчальних закладів до виконання професійних обов'язків необхідно віднесення таких ключових складників, як:

1) теоретична підготовка та надання практичних навичок;

2) придбання професійних умінь та навичок;

3) професійне бажання та позитивне ставлення до отримання робітничої професії.

\section{1. Формування професійної компетентності}

Приблизно 90\% випускників загальної освіти не досягають фізичної досконалості та відчувають захворювання й різні пристрасті. На середньому рівні у десять років діти вживають сигарети. Соціальний фактор вагомо впливає на вживання наркотиків й алкоголю5.

Перелік наявних проблем продовжується нарощуванням. Навпаки, 3 точки зору елементарної логіки, кожній особі необхідно: свобода від власних жахів, рівновага, співвідношення з громадськістю, формулювання та досягнення мети, постійний пошук з утворення та збереження дружби, кохання та статус коханого тощо. Суспільство розуміє важливість процесу виховання.

Наприклад, директор Grier School (США) підкреслює: «Мета школи - формулювання щасливої, здорової та творчої особистості, що спроможне досягненням мрії, збереження родини та власної впевненості. А також виховання гідного, чесного, стійкого громадянина, що поважає себе та спільноту» ${ }^{6}{ }^{7}$.

Пропонується понад тридцять рекомендацій Ради Європи стосовно диференційованого підходу щодо стосунків 3 різними віковими категоріями засуджених та ув'язнених: підлітками, юнаками та дорослими ${ }^{8}$. У безпосередній пенітенціарній практиці постійно виникають труднощі, що пов'язані з режимом стосунків 3 неповнолітніми та дорослими засудженими та ув'язненими, а також проблематикою працевлаштування під час згасання обмеження виробничих ресурсів установи виконання покарань. Оптимізація виховної корекційної

\footnotetext{
5 Gąsior K. Diversifying childhood experiences of Adult Children of Alcoholics. Alcoholism and Drug Addiction. Elsevier. 2014. Vol. 27(4). P. 289-304. URL: https://www.sciencedirect.com/ science/article/pii/S0867436114700215.

6 Stepanenko M. Magazine "Foreign education”. 2003. Vol. 2.

7 Diukareva M.M. Project representation "Education Reforming" (Personality formation programs introduction into Educational system). Procedia - Social and Behavioral Sciences. 2016. Vol. 217. P. 626-630. DOI: 10.1016/j.sbspro.2016.02.076.

8 Stratiev B. Osnovni mezhdunarodni aktove po penitentsiarno pravo. Zatvorno delo, kn. 3 , 2011. P. $15-27$.
} 
роботи із засудженими у обставинах поліпшення та впровадження заходів індивідуальних співвідношень ${ }^{9},{ }^{10}$ вимагає поглибленого вивчення віково-психологічних особливостей різних поколінь, що є складовою частиною сегментів загратних співмешканців. Вищезазначені тенденції викреслюються необхідністю концептуального відображення віково-психологічних особливостей засуджених та ув'язнених під час заходів пенітенціарного лікування та корекції ${ }^{11}$.

Вирішення проблематики (визначається терміном «формування професійної компетентності», особистість високоефективна, мотивована із безліччю позитивних якостей та без серйозних психоемоційних проблем) критично важливе стосовно кожного громадянина. Надається можливість ефективно та позитивно із користю щодо суспільства загалом, тобто уникнення або зменшення проблематики щодо вживання наркотиків, алкоголю, паразитизму, усунення злочину, лікування алкоголізму та психічних захворювань тощо. Відповідно, визначення зазначеної проблематики однієї з найбільш пріоритетних стосовно науки, освіти й суспільства загалом.

Встановлено, що загальні аспекти функціонування навчальних закладів при установах виконання покарань висвітлюються у багатьох дослідженнях. Проте питання формування у засуджених професійної компетентності під час отримання робітничої професій у системі ПТО пенітенціарної структури України не було креативним напрямом окремого наукового дослідження.

\section{2. Рівні сформованості професійної компетентності}

Досліджуючи роль діагностики у визначенні ефективності організації професійно-технічної освіти, В. Пурін ${ }^{12}$ констатує, що необхідно розглядати «якісним або кількісним визначенням, виявленням, вимірюванням фактичного стану будь-якої властивості, явища, процесу, що застосовує спеціальні способи, методи та прийоми». Діагностування розглядається як діяльність щодо визначення та вивчення ознак, що характеризується станом системи сформованості рівня професійної

9 Traykov Zdr. Nakazatelno-izpalnitelno pravo (penitentsiarno pravo). Izd. "Albatros", Sofia, 2007.

10 Kovachev A., Madzharov E., Momchev D., Nikolov P., Petrov Z., Despodov I., Grozev E. Kontseptsiya za vazpitatelnata rabota s lishenite ot svoboda. Zatvorno delo, kn. 3-4, 1990. P. 3-17.

11 Madzharov E.A. Age-psychological characteristics of inmates. Procedia - Social and Behavioral Sciences. 2016. Vol. 217, pp. 92-100.

12 Purin V.D. Pedagogy of secondary vocational education. Rostov-na-Donu : Phoenix, 2006. 256 p. (in Russian). 
компетентності слухачів, що здобувають професійно-технічну освіту у навчальних закладах пенітенціарної структури України. Діагностика здійснюється з метою чіткого встановлення реального стану сформованості професійної компетентності слухачів, а також щодо запобігання порушень та вдосконалення практичних механізмів формування у системі професійно-технічної освіти пенітенціарної структури України.

Згідно з логікою розглядуваного дослідження доцільне діагностування та чітке встановлення рівня сформованості професійної компетентності слухачів навчальних закладів системи професійно-технічної освіти пенітенціарної структури України. Саме від компетентного впровадження виділення рівневої градації безпосередньо залежить діалектичний характер змін слухачів у галузі професійної компетентності. У дослідженні під рівнем градації розуміється співвідношення вищих та нижчих ступенів сформованості слухачами показників професійної компетентності. Перш за все висновки Г. Жукова ${ }^{13}$ відзначають, що у професійно-технічному навчанні виділяється чотири рівні:

- 1-й рівень - визначення процесів щодо властивостей об'єктів галузі, що вивчається (знання - знайомство);

- 2-й рівень - репродуктивні дії здійснюються шляхом самостійного відтворення та застосування отриманої раніше інформації або виконання відомої раніше дії (знання - копіі);

- 3-й рівень - продуктивні дії або діяльність за зразком. У цьому разі набувається нова інформація під час процесу самостійної побудови або зміни методики виконання професійної дії (знання - частково інноваційне);

- 4-й рівень - творчість дії, що виконується на будь-яких об'єктах шляхом самостійного конструювання новаційних методик стосовно виконання завдань, у результаті отримується об’єктивно нова інформація (знання - інноваційна трансформація).

Відповідно до теорії рівневого підходу С. Рубінштейна ${ }^{14}$ кожен наступний рівень розвитку відрізняється від попереднього спрямованістю щодо констатації поступового руху. Реалістичність факту динамічності рівневої структури прийнята основною, передбачається закономірний порядок переходу від нижчого до вищого рівня, від простого до складного. Зазначений підхід дасть можливість дослідження

13 Zhukov G.N., Matrosov P.G. General and professional pedagogy : a textbook. Moskva : Alpha-M: INFRA-M, 2013. 448 p. (in Russian).

14 Rubinstein S.L. The principle of creative initiative. T. 2. High school scholarly notes, Odessa, 1992. P. $153-160$ (in Russian). 
теоретичної та практичної зміни, що володіє значущим характером під час процесу формування у слухачів професійної компетентності. Характеристика рівнів сформованості професійної компетентності слухачів навчальних закладів системи ПТО пенітенціарної структури України подано у таблиці 1.

Таблиця 1

Характеристика рівнів сформованості професійної компетентності слухачів навчальних закладів системи професійно-технічної освіти пенітенціарної структури України

\begin{tabular}{|c|c|}
\hline \begin{tabular}{|c|} 
Рівень \\
компетентності
\end{tabular} & Критерії та пояснення \\
\hline 1 & 2 \\
\hline \multirow{4}{*}{$\begin{array}{l}\text { Стихійний } \\
\text { (низький) }\end{array}$} & $\begin{array}{l}\text { Мотиваційний: відсутність зовнішніх та внутрішніх } \\
\text { мотивацій підвищення рівня професійної компетент- } \\
\text { ності щодо дій, спонукаючи страх; відсутність інтересу } \\
\text { до професійної діяльності; повна відсутність потреби } \\
\text { удосконалення мотивації; відсутність потреби у досяг- } \\
\text { ненні професійного успіху, слухачі займають позицію } \\
\text { стороннього спостерігача, відсутність бажання змін у } \\
\text { досягненні професіоналізму під час придбання робіт- } \\
\text { ничої професії. }\end{array}$ \\
\hline & $\begin{array}{l}\text { Змістовий: здійснюється неусвідомлений вибір робіт- } \\
\text { ничої професії; не сформовано теоретичні знання, від- } \\
\text { сутність бажання придбання позитивних результатів } 3 \\
\text { удосконалення професійної компетентності; іноді вико- } \\
\text { нується обов'язкове навчальне завдання, відсутність праг- } \\
\text { нення до підвищення освітнього рівня, а також відсутність } \\
\text { елементарної зацікавленості під час навчального процесу } \\
\text { стосовно робітничої професії. }\end{array}$ \\
\hline & $\begin{array}{l}\text { Практичний: сформований низький рівень умінь та } \\
\text { навичок самостійного проєктування вдосконалення осо- } \\
\text { бистої професійної компетентності; практичні професійні } \\
\text { завдання виконуються примусово та за зниженою резуль- } \\
\text { тативністю; відсутність перспективності та доцільності } \\
\text { щодо отримання професійно-технічної освіти та робітни- } \\
\text { чої професії після відбування терміну покарання. }\end{array}$ \\
\hline & $\begin{array}{l}\text { Результативний: низький рівень особистості та про- } \\
\text { фесійно важливої якості; відсутність вмінь та навичок } \\
\text { здійснення об'єктивної самооцінки особистих досягнень } \\
\text { у галузі професійної компетентності; відсутність умінь та } \\
\text { навичок прийняття рішення щодо необхідності прогно- } \\
\text { зування та коригування саморозвитку під час отримання } \\
\text { професійної компетентності. }\end{array}$ \\
\hline
\end{tabular}


Таблиця 1 (продовження)

\begin{tabular}{|c|c|}
\hline 1 & 2 \\
\hline \multirow{4}{*}{$\begin{array}{l}\text { Репродуктивний } \\
\text { (середній) }\end{array}$} & $\begin{array}{l}\text { Мотиваційний: підвищення професійної компетент- } \\
\text { ності збуджується зовнішніми факторами; ситуативно } \\
\text { проявляється інтерес до майбутньої робітничої профе- } \\
\text { сії; цінність професійної компетентності усвідомлюєтья } \\
\text { лише частково; іноді проявляється потреба у досягнені } \\
\text { професійного успіху, проте активні зусилля слухачем не } \\
\text { застосовуютья. }\end{array}$ \\
\hline & $\begin{array}{l}\text { Змістовий: вибір робітничої професії здійснено впли- } \\
\text { вом зовнішніх чинників - поверхневі теоретичні знання та } \\
\text { постійний тиск зовнішніх спонукань; займається вдоско- } \\
\text { наленням професійної компетентності завдяки цілеспря- } \\
\text { мованому впливу викладачів та здійснюється виконання } \\
\text { елементарних навчальних завдань; прагнення до підв-- } \\
\text { щення освітнього рівня розвинене на низькому рівні, при- } \\
\text { таманність, безсистемна зацікавленість у придбанні робіт- } \\
\text { ничої професії. }\end{array}$ \\
\hline & $\begin{array}{l}\text { Практичний: часткова сформованість умінь та навичок } \\
\text { самостійно проєктувати вдосконалення професійної ком- } \\
\text { петентності; іноді (за настроєм) виконуються практичні } \\
\text { професійні завдання; незначна увага щодо перспективи } \\
\text { отримання професійно-технічної освіти загалом та робіт- } \\
\text { ничої професії стосовно перспективи після відбування } \\
\text { терміну покарань. }\end{array}$ \\
\hline & $\begin{array}{l}\text { Результативний: низький рівень розвитку особистості } \\
\text { та професійної спрямованості; явно підвищена або зани- } \\
\text { жена самооцінка професійної компетентності та перспек- } \\
\text { тива особистих досягнень; частково сформовані вміння } \\
\text { та навички під час прийняття рішення щодо необхідності } \\
\text { прогнозування й коригування саморозвитку у галузі отри- } \\
\text { мання професійної компетентності. }\end{array}$ \\
\hline \multirow{2}{*}{$\begin{array}{l}\text { Продуктивний } \\
\text { (достатній) }\end{array}$} & $\begin{array}{l}\text { Мотиваційний: підвищення рівня професійної компе-- } \\
\text { тентності здійснюється впливом зовнішніх і внутрішніх } \\
\text { чинників; формується інтерес до майбутньої професійної } \\
\text { діяльності за обраною робітничою професією; цінність } \\
\text { професійної компетентності усвідомлюється, є внутрішне } \\
\text { прагнення до позитивних змін; здійснюютья помірні } \\
\text { зусилля до зазначеного рівня. }\end{array}$ \\
\hline & $\begin{array}{l}\text { Змістовий: вибір робітничої професії здійснено свідомо, } \\
\text { спостерігаєтьяя відсутність цілісної системи у діяльності } \\
\text { щодо вдосконалення професійної компетентності; само- } \\
\text { стійно виконується більшість навчальних завдань; під час } \\
\text { отримання робітничої професії спостерігається прагненя } \\
\text { до підвищення освітнього рівня, іноді спостерігається } \\
\text { особиста творчість під час навчального процесу. }\end{array}$ \\
\hline
\end{tabular}


Таблиця 1 (закінчення)

\begin{tabular}{|c|c|}
\hline 1 & 2 \\
\hline \multirow[b]{2}{*}{$\begin{array}{l}\text { Продуктивний } \\
\text { (достатній) }\end{array}$} & $\begin{array}{l}\text { Практичний: належний рівень сформованості та вдо- } \\
\text { сконалення професійної компетентності, вміння само- } \\
\text { стійного проєктування; виконуються практичні завдання } \\
\text { самостійно й за допомогою викладачів; усвідомлюються } \\
\text { певні позитивні перспективи під час отримання профе- } \\
\text { сійно-технічної освіти та робітничої професії після відбу- } \\
\text { вання терміну покарань. }\end{array}$ \\
\hline & $\begin{array}{l}\text { Результативний: розвинена активність, що використову- } \\
\text { ється раціональними методами та формами вдосконалення } \\
\text { професійної компетентності стосовно обраної робітничої } \\
\text { професії; організується частково пошукова діяльність } 3 \\
\text { оволодіння адекватною самооцінкою у галузі професійної } \\
\text { компетентності та особистих досягнень; сформованість } \\
\text { умінь та навичок щодо прийняття рішення необхідності } \\
\text { прогнозування й коригування професійної компетентно- } \\
\text { сті, поліпшення рефлексії, корективи та інновації впрова- } \\
\text { джуються у разі істотної потреби. }\end{array}$ \\
\hline \multirow{4}{*}{$\begin{array}{l}\text { Творчий } \\
\text { (високий) }\end{array}$} & $\begin{array}{l}\text { Мотиваційний: підвищення рівня професійної компе- } \\
\text { тентності життєво необхідно, що зумовлено внутрішніми } \\
\text { стимулами, інтерес до майбутньої професійної діяльності } \\
\text { та потреба у досягненні професійного успіху, що перед- } \\
\text { бачає усвідомлення систематичного й цілеспрямованого } \\
\text { вдосконалення. }\end{array}$ \\
\hline & $\begin{array}{l}\text { Змістовий: здійснюється безперервна самоосвіта, } \\
\text { успішно реалізується програма самовдосконалення теоре- } \\
\text { тичних знань за обраною робітничою професією; власти- } \\
\text { вість достатнього рівня ступеня творчості щодо освоєння } \\
\text { обраної робітничої професії, самостійно визначаються } \\
\text { практичні шляхи вдосконалення професійної компетент- } \\
\text { ності та є достатній рівень активності щодо підвищення } \\
\text { власного освітнього рівня. }\end{array}$ \\
\hline & $\begin{array}{l}\text { Практичний: самостійно та цілеспрямовано проєктується } \\
\text { вдосконалення професійної компетентності; регулярно } \\
\text { виконуються практичні професійні завдання; повноцінно } \\
\text { усвідомлюється позитивна перспектива під час отримання } \\
\text { професійно-технічної освіти та використання отриманих } \\
\text { знань, умінь та навичок після терміну відбування покарань. }\end{array}$ \\
\hline & $\begin{array}{l}\text { Рефлексивний: розвинена адекватна рефлексійна діяль- } \\
\text { ність, самостійно та цілеспрямовано використовуються } \\
\text { оптимальні способи й форми вдосконалення професійної } \\
\text { компетентності за обраною робітничою професією; орга- } \\
\text { нізується пошукова та творча діяльність, що спрямована } \\
\text { на особисті досягнення; самостійно прогнозується й кори- } \\
\text { гується успішність під час об'єктивного оцінювання. }\end{array}$ \\
\hline
\end{tabular}




\section{3. Оцінка рівня професійної компетентності слухачів навчальних закладів системи професійно-технічної освіти пенітенціарної структури України}

\section{1. Умови дослідницького спрямування}

Запропоновано робочу гіпотезу, що слухач ПТО пенітенціарної структури володіє належними (високим (творчим) і достатнім (продуктивним)) рівнями професійної компетентності, активно розвивається та отримує професійно-технічну підготовку у навчальному закладі системи ПТО пенітенціарної структури України. Вважається, що належний рівень сформованості професійної компетентності сприятиме позитивній ресоціалізації та адаптації особистості у соціумі після звільнення з місць позбавлення волі.

Здійснення констатуючого етапу експериментального дослідження під час отримання достовірної інформації стосується рівневої характеристики стану сформованості професійної компетентності слухачів. Умови процесу - дотримування вимог щодо надання робітничої професії у професійно-технічних навчальних закладах пенітенціарної структури України:

- детермінованість - передбачення щодо дотримання конкретних інструкцій та певних педагогічних механізмів під час проведення діагностичного дослідження;

- масовість - залучення значної кількості респондентів під час проведення діагностичних досліджень щодо здійснення обгрунтованості та науково зважених висновків;

- результативність - здійснення діагностики для передбачення можливості отримання чітких, однозначних і узагальнених результатів у контексті педагогічної виваженості та коректності визначення перспективних шляхів удосконалення показників професійної компетентності.

\section{2. Діагностичний інструментарій визначення стану сформо- ваності професійної компетентності}

Під час організації констатуючого етапу експерименту впроваджено: діагностичні методики, стандартизовані тестування, спеціально розроблені авторські анкетування, опитування та методики педагогічного консиліуму. Діагностичний інструментарій спрямовано на вимірювання стану сформованості виділених показників професійної компетентності слухачів навчальних закладів системи ПТО пені- 
тенціарної структури України. Звертається увага на факт надійності результатів забезпечення циклічності окремих вимірів показників; впровадження уніфікованої процедури дослідження; застосування інноваційного та науково-виваженого діагностичного інструментарію. Під час використання діагностичного інструментарію здійснено дослідження прагнення отримання чітких та однозначних результатів, що достовірно та валідно (табл. 2).

Таблиця 2

Діагностичний інструментарій визначення стану сформованості професійної компетентності слухачів навчальних закладів системи професійно-технічної освіти пенітенціарної структури України (компонент - цілемотиваційний; критерій - якість)

\begin{tabular}{|l|l|}
\hline \multicolumn{1}{|c|}{ Показники } & \multicolumn{1}{|c|}{ Діагностичний інструментарій } \\
\hline \multicolumn{1}{|c|}{$\mathbf{1}$} & \multicolumn{1}{|c|}{$\mathbf{2}$} \\
\hline $\begin{array}{l}\text { Сформованість внутрішніх мотива- } \\
\text { цій для вдосконалення професійної } \\
\text { компетентнсті }\end{array}$ & $\begin{array}{l}\text { Методика діагностики навчальної } \\
\text { мотивації (А. Реан та В. Якунін у } \\
\text { авторській модифікації) }\end{array}$ \\
\hline $\begin{array}{l}\text { Iнтерес до майбутньої професійної } \\
\text { діяльності }\end{array}$ & $\begin{array}{l}\text { Бесіда та авторське анкетування } \\
\text { слухачів. Методика діагносики } \\
\text { потреби щодо досягнення професій- } \\
\text { ного успіху }\end{array}$ \\
\hline $\begin{array}{l}\text { Потреба досягнення професійного } \\
\text { успіху }\end{array}$ & $\begin{array}{l}\text { Досягнення професійного успіху за } \\
\text { Т. Елерсом }\end{array}$ \\
\hline Свідомий вибір робітничої професії & $\begin{array}{l}\text { Тест «Інтегральна задоволеність } \\
\text { працею» }\end{array}$ \\
\hline $\begin{array}{l}\text { Якість результатів діяльності } \\
\text { щодо удосконалення професійної } \\
\text { компетентності }\end{array}$ & $\begin{array}{l}\text { Методика діагностики. } \\
\text { Методика педагогічного консиліуму }\end{array}$ \\
\hline $\begin{array}{l}\text { Прагнення до підвищення освітнього } \\
\text { рівня та зацікавленості відповідно до } \\
\text { власної робітничої професії }\end{array}$ & $\begin{array}{l}\text { Авторське експрес-опитування при- } \\
\text { вабливості праці (В. Снетков) }\end{array}$ \\
\hline $\begin{array}{l}\text { Вміння та навички самостійного } \\
\text { проєктвання й вдосконалення про- } \\
\text { фесійної компетентності }\end{array}$ & $\begin{array}{l}\text { Тест «Якір кар’єри» } \\
\text { (Е. Шейн, переклад й адаптація } \\
\text { В. Чікер, В. Вінокурова) }\end{array}$ \\
\hline $\begin{array}{l}\text { Якість виконання практичних профе-- } \\
\text { сійних завдань }\end{array}$ & $\begin{array}{l}\text { Експертна оцінка майстрами вироб- } \\
\text { ничого навчання якості виконання } \\
\text { практичних професійних завдань }\end{array}$ \\
\hline $\begin{array}{l}\text { Вміння та навички, що дають мож- } \\
\text { ливість визначати потенціал під час } \\
\text { отримання професійно-технічної } \\
\text { освіти після відбування покарань }\end{array}$ & $\begin{array}{l}\text { Тест «Шкала оцінки потреби у } \\
\text { досягненні» за Ю. Орловим }\end{array}$ \\
\hline
\end{tabular}


Таблиця 2 (закінчення)

\begin{tabular}{|l|l|}
\hline \multicolumn{1}{|c|}{$\mathbf{1}$} & \multicolumn{1}{|c|}{$\mathbf{1}$} \\
\hline $\begin{array}{l}\text { Розвиток професійного прогнозу- } \\
\text { вання й важливих та особистих яко- } \\
\text { стей слухачів. Методика виявлення } \\
\text { та аналіз професійно важливих яко- } \\
\text { стей слухачів }\end{array}$ & $\begin{array}{l}\text { Методика визначення рівня спеці- } \\
\text { альнстей системи } \\
\text { «Людина-техніка». Визначення } \\
\text { деструктивних установок у міжосо- } \\
\text { бистих відносинах } \\
\text { (В. Бойко) }\end{array}$ \\
\hline $\begin{array}{l}\text { Рефлексія професійної компетентно-- Діагностика професійного вигоряння } \\
\text { сті й особистих досягнень }\end{array}$ & $\begin{array}{l}\text { (К. Маслач, С. Джексон авторської } \\
\text { модифікації) }\end{array}$ \\
\hline $\begin{array}{l}\text { Самосвідомості та коригування } \\
\text { саморозвитку особистості }\end{array}$ & $\begin{array}{l}\text { Саморозвиток особистості } \\
\text { (Е. Роговий) }\end{array}$ \\
\hline
\end{tabular}

Сконцентруємося на розгляді характеристики результатів сформованості показників мотиваційного критерію. Показник «сформованість внутрішніх мотивів для вдосконалення професійної компетентності» перевіряється за допомогою методики діагностики навчальної мотивації (А. Реан та В. Якунін у авторській модифікації). Зокрема, з'ясовуються такі мотивації, як: комунікативність, уникнення престижу, новаційність, професійність, творча самореалізація, навчально-пізнавальна або соціальність, що вважається за краще у слухачів під час отримання професійної освіти у навчальних центрах пенітенціарної структури України.

\section{3. Процес та аналіз дослідження}

Під час процесу дослідження встановлено, що у більшості слухачів домінується мотивація уникнення. Наприклад, 247 (61,75\%) респондентів отримали оцінку «5» (п'ять) 3 питань, що підкреслюють мотивацію. Зокрема, найбільшою кількістю отриманих балів слухачами здійснено оцінка питання: «Навчання - можливість уникнення дисциплінарного стягнення стосовно результатів депозитивного відношення до навчального процесу». Встановлено друге місце мотивації підвищення рівня професійної компетентності - комунікативні мотивації. 133 (33,25\%) респондентів отримали оцінку «4» (добре) 3 питання: «Навчання - потреба щодо впевненості на майбутнє та особисто». Третя позиція слухачів - мотивація престижу, отримано оцінка «3» (три) під час відповіді на питання: «Навчання - рівень авторитетності до підвищення рейтингу стосовно співвідношень із викладачами та адміністрацією пенітенціарної установи». Відзначаємо факт, що професійними мотиваціями творчої самореалізації практично 
слухачі не зацікавлюються. Зокрема, найменшу кількість балів 1 (один) зафіксовано стосовно питань: «Навчання для забезпечення та підвищення успішності майбутньої професійної діяльності» та «Навчання для перспективи отримання високого кваліфікаційного рівня робітничої професії». Встановлено, що слухачі не керуються мотивацією зацікавленості та навчальним пізнанням. Узагальнення результатів констатує професійну мотивацію вагою 51 (12,75\%) респондент з опитаних 400 слухачів навчальних закладів системи професійно-технічної освіти пенітенціарної структури України.

Метою з'ясування рівня сформованості показників до інтересу майбутньої професійної діяльності є бесіда зі слухачами. Під час бесіди встановлено, що незначна кількість слухачів, а саме 45 (11,25\%) респондентів, вважає за краще факт соціальності спрямованості навчання. Засуджені прагнуть під час навчання та отримання освіти підвищити власний загальноосвітній й культурний рівні. Мета - адаптація, реабілітація, соціальні покликання до виправлення та повернення у соціум. Поступове переконання, що від успіхів під час навчання залежить власне майбутнє становище у суспільстві після відбування покарань.

До іншої групи віднесено засуджених із інтересами до майбутньої професійної діяльності, що пов'язано з отриманням певної матеріальної винагороди.

Зокрема, третина засуджених - 123 (30,75\%) опитаних визнали, що основна мета отримання робітничої професії пов'язана з прагненням умовно-дострокового звільнення.

Завдяки відмінним успіхам під час навчання надається можливість до аспекту додаткових пільг. Третю групу засуджених акцентовано до загрози стягнень та застосування санкцій. Встановлено, що $111(27,75 \%)$ опитаних констатували, що робітнича професія отримується за мотивацією змушення зовнішнього фактору. Слухачам прогнозується уникнення покарання під час невиконання наказу адміністрації. Найбільшою групою засуджених підтримуються нейтральні інтереси до майбутньої професійної діяльності. 3'ясовано, що 121 (30,25\%) слухач навчається тому, що зайнятості під час відбування покарань не існує.

Під час розробки анкети здійснено дослідження ступеня розвитку інтересів до професійної компетентності. Під час анкетування слухачами відзначається, що найчастіше вивчається теоретичний матеріал, отримується завдання від викладача. Рідко за власною ініціативою вивчається спеціальна література, а тому виконується завдання, що обов'язково 
перевіряється викладачем. 22 (5,5\%) слухачі, відповідаючи на питання щодо охайності оформлення письмових завдань, відповіли «завжди», водночас більшість, а саме 305 (76,25\%) респондентів, вибрала відповідь «рідко». Вражають результати відповідей засуджених на питання: «Я згоден брати участь у конференціях, заходах або зборах, якщо це стосується власної майбутньої робітничої професії»: 41 (10,25\%) слухач констатував, що погодиться «завжди», 295 (73,75\%) слухачів відповідали «ніколи», інші респонденти написали відповідь - «рідко».

Анкетуванням здійснено дослідження градації розвитку інтересів до вдосконалення професійної компетентності слухачів навчальних закладів пенітенціарної структури України. Зокрема, встановлено, що у більшості слухачів переважає байдужість, епізодична та показна зацікавленість. Під час опитування з'ясовано, що інтерес - професійна потреба притаманний 39 (9,75\%) слухачам. Функціональний інтерес діагностовано стосовно 55 (13,75\%) слухачів. Інтерес як допитливість отримано у 66 (16,5\%) слухачів. Встановлена систематичність 3 виявлення інтересу до майбутньої професійної діяльності у 43 (10,75\%) слухачів. Частіше - у 58 (14,5\%) слухачів; рідше - 238 (59,5\%) слухачів; «ніколи» - у 61 (15,25\%) слухача.

Під час бесід із засудженими та проведеного авторського анкетування встановлено, що між інтересом засуджених до майбутньої професійної діяльності та рівнем сформованості професійної компетентності є чіткий взаємозв'язок. Зокрема, чим вищий рівень ресоціалізації засуджених у колективі, тим сумлінніше у слухачів спостерігається інтерес до поліпшення навчання. Відповідно, вищий рівень професійної компетентності стосовно обраної робітничої професії, а також встановлення зворотного зв'язку - сумлінне відношення слухачів до навчання, тобто констатується підвищення рівня ресоціалізації.

Метою дослідження рівня сформованості показників мотиваційного критерію $є$ потреба в досягненні професійного успіху та залученні методики діагностики потреби Т. Елерса. Під час дослідження встановлено, що 112 (28,0\%) слухачів набрано 10 балів, тому діагностується низька потреба у досягненні професійного успіху. Зокрема, респондентами відзначається старанність слухачів під час виконання професійного завдання. Однак враховується зацікавленість у іншій галузі, тобто завдання, що не є основною функцією працездатності. Більше приваблює діяльність, тобто інша робота.

Встановлено, що 179 (44,75\%) респондентів набрали 11-16 балів, що відповідає середньому рівню потреби в досягненні професійного 
успіху. Характерність факту визнання респондентами досягнення у праці не завжди однакова. Багато професійних справ слухачами не виконуються до кінця, а також іноді відкладається завдання негайного виконання. 79 (19,75\%) опитаних слухачів набрали 17-20 балів, отже, встановлено помірно високий рівень потреби під час досягнення професійного успіху. Під час прийняття професійного рішення слухачами здійснюється виконання завдань краще. Встановлено, що 30 (7,5\%) респондентів набрали більше 21 бала, що відповідає творчому рівню складання потреби у досягненні професійного успіху. Відповідаючи на питання, слухачі визнавали, що вони під час виконання професійного завдання не розраховують на допомогу інших, а покладаються лише на власний досвід. Наприкінці вихідних або святкових діб слухачі радіють виходу виконання завдання. Отже, мотивація до професійного успіху респондентів впливає на реальність досягнення потреби засобом професійної діяльності. У таблиці 3 представлено узагальнення результатів сформованості показників мотиваційного критерію.

Таблиця 3

Результати сформованості показників професійної компетентності слухачів навчальних закладів системи професійно-технічної освіти пенітенціарної структури стосовно мотиваційних критеріїв $(\%, n=400)$

\begin{tabular}{|c|c|c|c|c|c|c|c|c|}
\hline \multirow[b]{4}{*}{ Показники } & \multicolumn{8}{|c|}{ Рівні } \\
\hline & \multirow{2}{*}{\multicolumn{2}{|c|}{$\begin{array}{l}\text { стихійний } \\
\text { (низький) }\end{array}$}} & \multicolumn{4}{|c|}{$\begin{array}{l}\text { репродуктивний } \\
\text { (продуктивний) }\end{array}$} & \multirow{2}{*}{\multicolumn{2}{|c|}{$\begin{array}{c}\text { творчий } \\
\text { (високий) }\end{array}$}} \\
\hline & & & \multicolumn{2}{|c|}{ (середній) } & \multicolumn{2}{|c|}{ (достатній) } & & \\
\hline & 焉 & $\begin{array}{c}\mathbf{y} \\
\%\end{array}$ & 贾 & $\begin{array}{c}\mathbf{y} \\
\%\end{array}$ & 舀 & $\begin{array}{l}\mathbf{y} \\
\%\end{array}$ & 嘿 & $\begin{array}{l}\mathbf{y} \\
\%\end{array}$ \\
\hline $\begin{array}{l}\text { Сформованість внутріш- } \\
\text { ніх мотивацій щодо вдо- } \\
\text { сконалення професійної } \\
\text { компетентності } \\
\end{array}$ & 105 & 26,25 & 190 & 47,5 & 54 & 13,5 & 51 & 12,75 \\
\hline $\begin{array}{l}\text { Iнтерес щодо майбутньої } \\
\text { професійної діяльності }\end{array}$ & 61 & 15,25 & 238 & 59,5 & 58 & 14,5 & 43 & 10,75 \\
\hline $\begin{array}{l}\text { Потреба у досягненні } \\
\text { професійного успіху }\end{array}$ & 112 & 28,0 & 179 & 44,75 & 79 & 19,75 & 30 & 7,5 \\
\hline Узагальнені результати & 93 & 23,17 & 202 & 50,6 & 63,7 & 16,0 & 41 & 10,3 \\
\hline
\end{tabular}




\section{ВИСНОВКИ}

Таким чином, констатується, що половина опитаних - 202 (50,5\%) респонденти щодо сформованості мотиваційного критерію професійної компетентності перебуває на репродуктивному рівні, стосовно 41 (10,25\%) слухача мотиваційний складник досягнення професійної компетентності сформований на творчому (високому) рівні.

Отже, на підставі інтерпретації результатів тестування «Інтегральна задоволеність працею» встановлено, що низький рівень задоволеності працею через неусвідомлений вибір робітничої професії характеризується діапазоном 1-24\% всієї набраної слухачами суми балів. Результати 101 (25,25\%) респондента. Встановлено, що 173 (43,25\%) слухачі мають середній рівень, 54 (13,5\%) респонденти мають високий рівень, адже вони набрали бали у межах 76-99\% від загальної суми, тобто 72 (18,0\%) респонденти - достатній рівень.

Основним завданням методики підготовки до професійної компетентності слухачів навчальних закладів системи ПТО пенітенціарної структури України є реалізація активної життєвої позиції. Процес багаторівневої структури становить елементи - вольові, емоційні, інтелектуальні прояви особистості тощо. Процес формування позитивних мотивацій навчання, що визначається внутрішнім ставленням слухача до процесу пізнання, та виховання слухачів навчальних закладів системи ПТО, що вагомо оптимізує професійну підготовку. Велику роль у системі мотивації відіграють мотиви розуміння суспільної та індивідуальної значущості досліджуваних умінь та навичок. С стійка потреба у вивченні фахових дисциплін. Мотиви дозволяють дати старт захопленості у слухачів майбутньою професією, відчуття відповідальності за результативність навчання. Таким чином, під час формування професійної компетентності слухачів навчальних закладів системи ПТО до навчального процесу з професійної підготовки є необхідність доцільного надання певного педагогічного впливу. Націлення формування інтересу до власної робітничої професії, прагнення під час досягнення зазначеної мети, стимулювання процесу підвищення професійної кваліфікації та компетентності.

\section{АНОТАЦІЯ}

У статті розглядається проблематика формування професійної компетентності слухачів навчальних закладів системи професійнотехнічної освіти пенітенціарної структури України. Визначено роль ефективності організації професійно-технічної освіти у формуванні 
професійної компетентності засуджених. Встановлено рівні сформованості професійної компетентності слухачів. Проведено діагностичні методики, стандартизовані тестування, спеціально розроблене авторське анкетування та опитування, методику педагогічного консиліуму. Слухач, що володіє високим (творчим) та достатнім (продуктивним) рівнями професійної компетентності, активно розвивається й отримує основну професійно-технічну підготовку як у вищих навчальних закладах освіти, так і Пенітенціарної служби України. Таким чином, це сприяє максимальному адаптуванню засудженого у соціумі після його звільнення $з$ місць позбавлення волі. Встановлено, що 102 (25,5\%) респонденти у період дослідження досягли успіхів під час придбання робітничої професії, виконуючи умови певних мотивацій, 229 (57,25\%) респондентів вважають досягнення успіхів лише частковими.

\section{ЛІТЕРАТУРА}

1. Gąsior K. Diversifying childhood experiences of Adult Children of Alcoholics. Alcoholism and Drug Addiction. Elsevier. 2014. Vol. 27(4). P. 289-304. URL: https://www.sciencedirect.com/science/article/pii/ S0867436114700215.

2. Stepanenko M. Magazine "Foreign education”. 2003. Vol. 2.

3. Diukareva M.M. Project representation "Education Reforming" (Personality formation programs introduction into Educational system). Procedia - Social and Behavioral Sciences. 2016. Vol. 217. P. 626-630. DOI: 10.1016/j.sbspro.2016.02.076.

4. Stratiev B. Osnovni mezhdunarodni aktove po penitentsiarno pravo. Zatvorno delo, kn. 3, 2011. P. 15-27.

5. Traykov Zdr. Nakazatelno-izpalnitelno pravo (penitentsiarno pravo). Izd. "Albatros", Sofia, 2007.

6. Kovachev A., Madzharov E., Momchev D., Nikolov P., Petrov Z., Despodov I., Grozev E., Kontseptsiya za vazpitatelnata rabota s lishenite ot svoboda. Zatvorno delo, kn. 3-4, 1990. P. 3-17.

7. Madzharov E.A. Age-psychological characteristics of inmates. Procedia - Social and Behavioral Sciences. 2016. 217, pp. 92-100.

8. Purin V.D. Pedagogy of secondary vocational education. Rostov-naDonu : Phoenix, 2006. 256 p (in Russian).

9. Zhukov G.N., Matrosov P.G. General and professional pedagogy: a textbook. Moskva : Alpha-M: INFRA-M, 2013. 448 p. (in Russian).

10. Rubinstein S.L. The principle of creative initiative. T. 2. High school scholarly notes, Odessa, 1992. P. 153-160 (in Russian). 
Information about authors:

Ollo V. P.,

ORCID ID: 0000-0003-1799-2299

$\mathrm{PhD}$, Director

State Educational Institution “Odessa training center № 14” under Administration of the State Penitentiary Service of Ukraine in Odesa

Region

2a, Krasnova str., Odessa, Ukraine

Sakno O. P.,

ORCID ID: 0000-0003-4672-6651

$\mathrm{PhD}$ (Tech),

Associate Professor at the Department of Vehicle Operation and Maintenance

Prydniprovska State Academy of Civil Engineering and Architecture 24A, Chernyshevsky str., Dnipro, Ukraine

DOI https://doi.org/10.30525/978-9934-588-43-3/2.15 